Diterima : 17-4-2020 Revisi : 19-6-2020 Dipublikasi : 25-6-2020

\title{
PERBANDINGAN PENYIMPANGAN PRINSIP KESOPANAN BUDAYA INDIA DAN PERANCIS DALAM FILM THE HUNDRED-FOOT JOUTNEY
}

\author{
Marisa Puteri Sekar Ayu Santosa \\ Universitas Airlangga \\ Jl. Dharmawangsa Dalam Selatan No.30, Airlangga, Kota Surabaya, Indonesia \\ Pos-el : santosa.marisa05@gmail.com
}

\begin{abstract}
Abstrack
This study aims to investigate the comparison of the deviations of the principle of politeness in Indian and French culture in a film called The Hundred-Foot Journey. Here the author uses Leech's theory of politeness principles which consists of maxims: (1) maxim of wisdom, (2) maxim of generosity, (3) maxim of praise, (4) maxim of humility, (5) maxim of compatibility, and (6) maxim of sympathy. Of these 2 cultures, only 3 maxims deviations were found consisting of: (1) deviations of wisdom maxims, (2) deviations of humility maxims, and (3) deviations of the maxims of agreement. The most common deviations in the principle of politeness in these two different cultures are maxim of agreement. The culture that often violates the maxim of agreement is Indian culture, which commits 16 violations, while France has 11 violations.
\end{abstract}

Keywords : the maxim, the deviation of the principle of politeness

\begin{abstract}
Abstrak
Penelitian ini mempunyai tujuan untuk mengivestigasi perbandingan dari penyimpangan prinsip kesopanan pada kebudayaan India dan Perancis dalam sebuah film yang berjudul The Hundred-Foot Journey. Disini penulis menggunakan teori prinsip kesopanan milik Leech yang terdiri dari maksim-maksim: (1) maksim kebijaksanaan, (2) maksim kedermawanan, (3) maksim pujian, (4) maksim kerendahan hati, (5) maksim kecocokan, dan (6) maksim kesimpatian. Dari 2 kebudayan ini, hanya ditemukan 3 penyimpangan maksim yang terdiri dari: (1) penyimpangan maksim kebijaksanaan, (2) penyimpangan maksim kerendahan hati, dan (3) penyimpangan maksim kesepakatan. Penyimpangan prinsip kesopanan yang paling sering terjadi di 2 budaya berbeda ini sama-sama maksim kesepakatan. Budaya yang sering melakukan pelanggaran maksim kesepakatan adalah budaya India, yang melakukan 16 buah pelanggaran, sedangkan Perancis sebanyak 11 buah pelanggaran.
\end{abstract}

Kata-kata kunci: maksim, penyimpangan prinsip kesopanan 


\section{PENDAHULUAN}

Bahasa digunakan sebagai alat komunikasi yang memiliki tujuan agar kita dapat dipahami oleh orang lain, maupun sebaliknya kita bisa memahami orang lain. Penggunaan bahasa digunakan sebagai sarana untuk mengungkapkan atau mengekspresikan pikiran, perasaan, emosi dan menyampaikan informasi atau pesan yang berupa gagasan atau ide. Bisa dikatakan juga bahwa bahasa digunakan agar lawan tutur mendapatkan kejelasan dalam memperoleh informasi yang disampaikan oleh penutur, sehingga komunikasi dapat berjalan dengan lancer dan efektif. Adakalanya dalam berbahasa, seseorang tidak mematuhi prinsip-prinsip komunikasi yang baik secara tidak disengaja. Akibatnya maksud dan tujuan dari tuturan yang diucapkan penutur kepada lawan tutur menjadi tidak jelas, hal ini mengakibatkan terjadinya penyimpangan terhadap prinsip-prinsip komunikasi.

Agar komunikasi dapat berjalan dengan lancar, penutur dan lawan tutur diharapkan mematuhi prinsipprinsip komunikasi. Salah satu prinsip-prinsip komunikasi adalah prinsip kesopanan, kesopanan biasanya mengacu pada perilaku, namun selain itu, kesopanan bisa dilihat dari tuturannya. Bahasa adalah cerminan dari kepribadian seseorang dan berpengaruh pada lawan tutur saat melakukan komunikasi. Tuturan yang menyakitkan, merugikan dan merendahkan orang lain merupakan sebuah tindakan yang melanggar prinsip kesopanan. Menurut Leech (2013:132), prinsip kesopanan terdapat maksimmaksim: (1) maksim kebijaksanaan, (2) maksim kedermawanan, (3) maksim pujian, (4) maksim kerendahan hati, (5) maksim kecocokan, dan (6) maksim kesimpatian.

Bentuk-bentuk komunikasi banyak ditemukan dalam kehidupan sehari-hari maupun dalam sebuah film, seperti dalam film The Hundred-Foot Journey. Film merupakan salah satu media komunikasi yang menarik untuk diteliti, karena terdapat banyak percakapan dan tuturan yang dilakukan oleh para tokoh, seperti pada film The Hundred-Foot Journey. Namun dalam percakapan dan tuturan yang terjadi di dalam film, adakalanya peserta tutur tidak maksimal dalam menangkap informasi sehingga menyebabkan terjadinya kesalahan komunikasi, dan hal ini dapat berdampak negative terhadap lawan tutur. Hal ini yang menarik penulis untuk meneliti tentang penyimpangan prinsip kesopanan yang dilakukan oleh para tokoh dalam film melalui percakapan atau tuturan yang diucapkan.

Film The Hundred-Foot Journey merupakan film yang bercerita tentang sebuah keluarga India yang merantau ke Prancis, dan mereka 
membuka sebuah restoran India disana. Secara kebetulan letak restoran ini tepat di seberang restoran Prancis yang terkenal. Film ini berdurasi kurang lebih 122 menit. Di dalam film ini ditemukan perbedaan budaya dan beberapa penyimpangan prinsip kesopanan yang dilakukan oleh dua latar belakang kultur yang berbeda. Tuturan pada setiap penyimpangan terhadap prinsip kesopanan yang dilakukan para tokoh memiliki maksud tertentu. Maksud yang terkandung dalam penyimpangan tersebut dapat dilihat melalui konteks yang melingkupi tuturan. Selain itu, terdapat faktor-faktor yang mempengaruhi sehingga muncul berbagai jenis penyimpangan prinsip kesopanan. Oleh karena itu, penulis tertarik untuk mengalisis lebih jauh penyimpangan prinsip kesopanan yang terjadi di dalam film ini.

\section{METODE PENELITIAN}

Penelitian

tentang penyimpangan prinsip kesopanan dalam film The Hundred-Foot Journey termasuk dalam penelitian deskriptif kualitatif, yaitu penelitian yang menghasilkan data deskriptif berupa kata-kata tertulis atau lisan dari orang-orang dan perilaku yang dapat diamati. Penelitian ini bertujuan untuk mendeskripsikan jenis-jenis penyimpanganprinsip kesopanan yang dilakukan para tokoh dalam film The Hundred-Foot Journey melalui tuturan-tuturan yang diucapkan. Dalam pengumpulan data, penulis menggunakan tahapan-tahapan sebagai berikut:

1. Penulis menonton dan menyimak film The HundredFoot Journey untuk mengetahui jalan cerita dari film tersebut.

2. Setelah mengetahui jalan cerita dari film tersebut, penulis menggunakan metode simak untuk menyimak penggunaan bahasa yang berupa tuturan dalam film The Hundred-Foot Journey dan membuat transkrip dialog dari film tersebut yang akan digunakan sebagai data penelitian.

3. Selanjutnya, penulis membaca transkrip dialog film The Hundred-Foot Journey secara keseluruhan untuk membantu pada saat proses penelitian.

4. Kemudian, tuturan-tuturan yang mengandung penyimpangan prinsip kesopanan dicatat dalam tabel klasifikasi data dengan menggunakan teknik catat.

5. Setelah data terkumpul, kemudian data diklasifikasikan berdasakan jenis penyimpangan prinsip kesopanan.

Leech (2013:6) menjelaskan bahwa pragmatik merupakan studi tentang makna dalam hubungannya dengan situasi-situasi ujar (speech situations). Situasi-situasi ujar tersebut merupakan konteks tuturan yang melatarbelakangi 
terjadinya suatu percakapan. Situasi ujar meliputi penutur dan lawan tutur, konteks sebuah tuturan, tuturan sebagai bentuk tindakan atau kegiatan dan tuturan sebagai produk tindak verbal. Sejalan dengan Leech, Levinson (2013:9) dan didukung Tarigan (2016:33), pragmatik adalah telaah mengenai relasi antarbahasa dan konteks yang merupakan dasar bagi suatu catatan atau laporan pemahaman bahasa. Dengan kata lain, pragmatik adalah kajian mengenai kemampuan pemakaian bahasa yang menghubungkan serta menyerasikan kalimat-kalimat dan konteks-konteks secara tepat.

Pragmatik memandang konteks sebagai pengetahuan bersama antara penutur dan lawan tutur, pengetahuan tersebut mengarah pada interpretasi suatu tuturan. Menurut Leech (2013:13), konteks diarikan sebagai aspek-aspek yang bersangkutan dengan lingkungan fisik dan sosial sebuah tuturan. Dengan kata lain, konteks sebagai suatu pengetahuan latar belakang yang dimiliki oleh penutur dan mitra tutur yang membantu menafsirkan makna tuturan, dan menjadi sarana penjelas suatu maksud dari tuturan yang diucapkan.

Dalam proses komunikasi, terjadi peristiwa sosial dalam interaksi antara penutur dengan mitra tutur dalam peristiwa atau situasi tertentu yang biasa disebut dengan peristiwa tutur. Menurut Dell Hymes (2012:58) suatu peristiwa tutur harus memenuhi 8 komponen, yang biasa disebut SPEAKING:

1. $S$ (setting $\mathcal{E}$ scene): setting meliputi waktu dan tempat tutur berlangsung, sedangkan scene meliputi situasi tempat dan waktu (suasana pembicaraan).

2. $\mathrm{P}$ (participant): pihak-pihak yang terlibat dalam penuturan seperti pembicara, lawan bicara, dan pendengar.

3. E (end): maksud atau tujuan yang ingin dicapai dalam proses tuturan yang terjadi.

4. A (act sequence): mengacu pada bentuk dan isi ujaran yang terkandung di dalamnya ketika seorang penutur sedang melakukan pembicaraan (action). Hal ini berkenaan dengan pilihan kata yang digunakan, hubungan antara apa yang diujarkan dengan topik yang sedang dibicarakan.

5. K (key): bertumpu pada nada, intonasi, semangat, dan cara ujaran itu diucapkan, apakah dengan senang hati, marah, bercanda atau sedih.

6. I (instrumentalities): menitikberatkan pada alat yang digunakan untuk menyampaikan tuturannya, seperti dengan bahasa lisan, tertulis ataupun isyarat.

7. N (norm): mengacu pada norma-norma yang berlaku di mana peristiwa tuturan tersebut terjadi, misalnya berhubungan denga cara bertanya atau menginterupsi. 
8. G (genres): mengarah pada bentuk dari penyampaian pesan tersebut, misalnya berupa dialog, prosa, puisi, pidato, dan sebagainya.

Menurut Wijana (2016:55), berbicara tidak selamanya berkaitan dengan sesuatu masalah yang bersifat tekstual, akan tetapi sering pula berhubungan dengan persoalan yang bersifat interpersonal. Sebagai retorika interpersonal pragmatik juga membutuhkan prinsip kesopanan, Leech (2013:132) mengatakan bahwa dalam prinsip kesopanan terdapat maksim-maksim:

1. Maksim kebijaksanaan: menekankan bahwa setiap peserta pertuturan harus meminimalkan kerugian orang lain, atau memaksimalkan keuntungan bagi orang lain. Maksim ini berpusat pada orang lain. Namun, seringkali terjadi penyimpangan dimana peserta tutur bertutur dengan tujuan untuk merugikan orang lain, tanpa memikirkan akibat dari ucapannya tersebut.

2. Maksim kedermawanan: menekankan bahwa peserta tuturnya dapat menghormati orang lain, inti dari maksim ini adalah buatlah keuntungan diri sendiri sekecil mungkin dan buatlah kerugian diri sendiri sebesar mungkin. Namun, seringnya terjadi penyimpangan adalah peserta tutur sering mengucapkan kata-kata yang tidak mengenakkan kepada lawan tutur dengan tujuan untuk memaksimalkan keuntungan kepada diri sendiri.

3. Maksim pujian atau kemurahan: menjelaskan bahwa seseorang dianggap santun apabila dalam bertutur selalu berusaha memberikan pujian kepada pihak lain. Didalam maksim ini, peserta tutur diharapkan agar tidak saling mengejek, mencaci atau merendahkan pihak lain, prinsip maksim ini adalah sedikit mungkin kecamlah orang lain dan pujilah orang lain sebanyak mungkin. Namun, seringnya terjadi penyimpangan, peserta tutur melanggar maksim pujian ini dengan membanggakan dirinya sendiri dan mengatakan sesuatu yang tidak mengenakkan hati seperti mengejek, mencaci dan merendahkan orang lain.

4. Maksim kerendahan hati: prinsip dari maksim ini adalah menekankan untuk tidak menonjolkan kemampuan yang kita miliki didepan orang lain, sebisa mungkin tonjolkan dan pujilah lawan tutur sebanyak mungkin. Namun seringkali terjadi penyimpangan bahwa peserta tutur menonjolkan diri yang berlebihan dan menganggap remeh 
kemampuan orang lain, sehingga tidak sesuai dengan maksim kerendahan hati.

5. Maksim kesepakatan atau pemufakatan atau kecocokan: ditekankan agar para peserta tutur dapat saling membina kecocokan atau kemufakatan dalam kegiatan bertutur, apabila terdapat kemufakatan atau kecocokan antara penutur dan lawan tutur dalam kegiatan penuturan, masing-masing dari mereka dapat dikatakan bersikap santun. Prinsip dari maksim ini adalah mengusahakan agar ketidaksepakatan antara diri sendiri dan pihak lain terjadi sedikit mungkin dan kesepakatan antara diri sendiri dan pihak lain terjadi sebanyak mungkin. Namun peserta tutur sering melakukan penyimpanan dengan menyatakan ketidaksetujuan atau ketidakcocokan terhadap idea tau saran yang diucapkan lawan tutur.

6. Maksim kesimpatian: didalam maksim kesimpatian peserta tutur diharapkan agar peserta tutur mengurangi rasa antipasti antara diri dengan pihak lain dan meningkatkan simpati sebanyak-banyaknya antara diri dengan pihak lain. Memelihara hubungan baik antara penutur dan lawan tutur merupakan salah satu bentuk keharmonisan yang terjalin. Namun, seringkali terjadi pelenggaran dalam maksim kesimpatian, peserta tutur bersikap antipasti terhadap orang lain, misalnya dengan tidak memberikan perhatian atau rasa simpati jika orang lain sedang mengalami kesusahan atau musibah.

Dengan penggunaan film sebagai objek kajian, dalam kamus Besar Bahasa Indonesia, film memilik arti selaput tipis yang dibuat dari seluloid untuk tempat gambar negatif dari sbuah objek. Selain itu, film memiliki arti lakon (cerita) gambar hidup. Menurut Pusat Apresiasi Seni Film, media yang sangat berpengaruh, melebihi media-media yang lain adalah film. Audio dan visual dalam film bekerja sama dengan baik sehingga membuat penonton tidak bosan dan lebih mudah mengingat. Dalam sebuah film terdapat banyak percakapan dan tuturan yang dilakukan antar pemain. Di dalam film The Hundred Foot Journey memiliki banyak percakapan atau tuturan. Film The Hundred-Foot Journey merupakan film yang bercerita tentang sebuah keluarga India yang merantau ke Perancis, dan mereka membuka sebuah restoran India disana. Secara kebetulan letak restoran ini tepat di seberang restoran Perancis yang terkenal.

\section{HASIL DAN PEMBAHASAN}


Berdasarkan hasil penelitian, penyimpangan prinsip kesopanan yang dilakukan oleh dua budaya yang berbeda, yaitu India dan Perancis dalam film The Hundred Foot Journey ini masing-masing meliputi 3 maksim dari 6 maksim yang ada, yaitu (1) penyimpangan maksim kebijaksanaan (India: 2 tuturan, Perancis: 4 tuturan), (2) penyimpangan maksim kerendahan hati (India:7 tuturan, Perancis: 3 tuturan), dan (3) penyimpangan maksim kesepakatan (India: 16 tuturan, Perancis: 11 tuturan). Berikut merupakan klasifikasi tentang jenis penyimpangan yang terjadi dan penjelasan komponen speaking di film The Hundred Foot Journey.

\section{a. Penyimpangan Kebijaksanaan}

Prinsip dalam maksim kebijaksanaan yaitu agar peserta tutur harus meminimalkan kerugian orang lain. Namun, seringkali peserta tutur mengucapkan tuturannya dengan tujuan untuk merugikan orang lain, tanpa memikirkan akibat yang terjadi dari ucapan tersebut. Pada penelitian yang dilakukan penulis, diperoleh 2 buah penyimpangan maksim kebijaksanaan pada budaya India dan 4 buah penyimpangan pada budaya Perancis. Berikut contoh percakapannya:

\section{Budaya India}

Mansur: I can't do this anymore, Papa. What are you trying to do?
Kill us all? We've been driving for days in this piece of junk. Enough of this crazy wandering. You know what? We were happier living under the flight path at Heathrow. At least we had a bloody home. (Saya tidak bisa melakukan ini lagi, Ayah. Apa yang kau coba lakukan? Membunuh kita semua? Kita telah berada di mobil berhari-hari mengunakan seonggok sampah ini. Cukup sudah untuk perjalanan gila ini. Kamu tahu apa? Kita lebih bahagia hidup dibawah tempat pesawat lalu lalang di Heathrow. Paling tidak kita mempunyai rumah.)

Papa: Wherever the family is, that is the home. (Dimanapun keluarga kita berada, disitulah rumah kita.)

Analisa menggunakan teori dari Dell Hymes (2012:58) yang terdiri dari 8 komponen yang biasa disebut SPEAKING:

Dialog ini berlatar tempat didalam mobil, perjalanan dari London menuju Perancis dengan situasi rem mobil rusak. Peserta tutur didalam dialog ini adalah Mansur (anak), Papa/Khadam (ayah). Maksud dari Mansur (anak) adalah merasa jengkel karena telah melakukan perjalanan dengan menyetir mobil selama berhari-hari tanpa tujuan pasti dan merasa hidup mereka sebelumnya lebih baik daripada sekarang, sedangkan sang ayah berpikir bahwa dimanapun mereka berada selama bersama keluarga telah 
merasa berada dirumah. Didalam dialog ini Mansur merasa kesal dengan ayahanya lalu membentak ayahnya, karena dia merasa tidak habis pikir dengan apa yang dipikiran ayahnya yang seolah terlihat seperti tidak ada arah dan ayahnya tidak mendengar siapapun selain dirinya sendiri. Dalam dialog ini, Mansur menyampaikan tuturannya kepada Ayahnya dengan kesal dan membentak. Tuturan yang dilakukan oleh peserta tutur dilakukan dengan lisan tanpa perantara seperti surat ataupun telepon. Tuturan yang diucapkan Mansur tidak sopan dan melanggar maksim kebijaksanaan karena ia telah merugikan ayahnya dengan mengucapkan kalimat "What are you trying to do? Kill us all? We've been driving for days in this piece of junk. Enough of this crazy wandering." Dan disini, tuturan diformulasikan dalam bentuk dialog.

\section{Budaya Perancis}

Papa: Oh, I bet you do. How much are they asking? (Aku bertaruh kamu melakukannya. Berapa banyak yang mereka minta?)

Hasan: Papa, please! (Papa, kumohon!)

Papa: One minute. Relax. (Tunggu sebentar. Santai).

Madame Mallory: Oh...You must understand that a property of this size in this village, would be very expensive. Well, I heard you asked for a discount in Claude's hotel. (Oh... Kamu harus mengerti bahwa semua property dengan ukuran seperti ini di desa ini pasti sangat mahal. Aku mendengar bahwa kamu meminta potongan harga di hotel Claude.)

Analisa menggunakan teori dari Dell Hymes (2012:58) yang terdiri dari 8 komponen yang biasa disebut SPEAKING:

Dialog pada film ini berlatar tempat di sebuah bangunan tua yang berbentuk restoran. Peserta tutur dalam dialog ini adalah Papa/Khadam (ayah), Hasan (anak), dan Madame Mallory (pemilik restoran Perancis). Maksud dari tuturan Madame Malory adalah menyindir Khadam yang membayar hotel saja meminta potongan harga, namun sekarang ingin membeli rumah yang harganya sudah pasti mahal. Di dalam dialog ini Madame Mallory merendahkan Khadam dan menganggap Khadam tidak mampu membeli bangunan tua ini karena dia menganggap bahwa Khadam tidak memiliki uang yang cukup. Nada dari ucapan Madam Mallory dengan tone yang biasa karena bermaksud mengejek. Di dalam dialog ini tuturan dilakukan dengan lisan tanpa perantara. Tuturan yang dilakukan Madame Mallory tidak sopan dan melanggar maksim kebijaksanaan karena ia telah merugikan Khadam dengan mengucapkan sindiran, 
"Oh... You must understand that a property of this size in this village, would be very expensive. Well, I heard you asked for a discount in Claude's hotel. Tuturan diformulasikan dalam bentuk dialog.

\section{b. Penyimpangan}

\section{Maksim}

\section{Kerendahan Hati}

Prinsip dalam maksim kerendahan hati ialah memuji diri sendiri sedikit mungkin dan kecamlah diri sendiri sebanyak mungkin. Namun, pada kenyataannya seringkali peserta tutur mengagung-agungkan atau menonjolkan sesuatu yang berlebihan dan menganggap orang lain remeh atau lebih rendah. Pada penelitian yang dilakukan oleh penulis, diperoleh 7 buah penyimpangan maksim kerendahan hati pada budaya India, dan 3 buah penyimpangan maksim kerendahan hati pada budaya Perancis. Berikut contoh dari percakapannya:

\section{Budaya India}

Papa: Madame, asking for discount doesn't mean I am poor. It means I am thrifty. I want to make an offer, to buy this restaurant. (Madame, meminta diskon tidak berarti saya miskin. Ini berarti saya hemat. Saya ingin melakukan penawaran untuk membeli restoran ini.)

Analisa menggunakan teori dari Dell Hymes (2012:58) yang terdiri dari 8 komponen yang biasa disebut SPEAKING:

Dialog dalam film ini berlatar tempat di sebuah bangunan tua yang berbentuk restoran. Peserta tutur dari dialog ini Papa/Khadam (ayah), Hasan (anak), dan Madame Mallory (pemilik restoran Perancis). Maksud tuturan dari Khadam adalah untuk membeli bangunan tua ini, dan menjelaskan bahwa dia mampu membeli bangunan ini karena dia tidak miskin melainkan hemat. Di dalam dialog ini Khadam merasa kesal dengan Madame Mallory yang menganggap dia tidak mempunyai cukup uang, maka dia bertutur bahwa dia adalah orang yang hemat. Khadam bertutur dengan nada kesal dan dengan membanggakan diri bahwa dia adalah orang yang hemat. Tuturan dilakukan dengan lisan tanpa perantara. Tuturan yang dilakukan Khadam tidak sopan dan melanggar maksim kerendahan hati, karena dia membanggakan dirinya sendiri, dengan mengatakan, ". It means I am thrifty. I want to make an offer, to buy this restaurant." Tuturan diformulasikan dalam bentuk dialog.

\section{Budaya Perancis}

Papa: Yes, enough of you. Always up there like a queen or something. You tell him, it's "classical. "What is "classical"? (Ya, sudah cukup 
untukmu. Selalu di atas sana bertingkah seperti ratu atau sesuatu. Kamu berkata padanya bahwa ini adalah sesuatu yang klasik. Apakah itu klasik?)

Madame Mallory: "Classical" comes from the word "class. "And that is what he will learn in my kitchen. He will learn how to cook with class. (Klasikal berasal dari kata kelas. Inilah yang akan dia pelajari dari dapurku. Dia akan belajar memasak dengan berkelas.)

Analisa menggunakan teori dari Dell Hymes (2012:58) yang terdiri dari 8 komponen yang biasa disebut SPEAKING:

Dialog dalam film ini berlatar tempat di restoran milik Khadam, pada saat Madame Mallory bernegosiasi dengan Khadam tentang keinginan Madame Mallory untuk mengangkat Hasan (anak Khadam) menjadi koki di restorannya. Peserta tutur dalam dialog Papa/ Khadam (Ayah), dan Madame Mallory (pemilik restoran Perancis). Maksud dari Madame Mallory di dalam tuturan adalah ingin membanggakan restoran miliknya, bahwa dari restorannya Hasan bisa mempelajari sesuatu yang berkelas. Di dalam dialog ini Madame Mallory merasa perlu membanggakan restorannya, karena dia merasa restorannya lebih berkelas daripada restoran milik Khadam. Madame Mallory bertutur dengan sombong dan membanggakan restoran miliknya. Tuturan pada dialog ini dilakukan dengan lisan tanpa perantara. Tuturan yang dilakukan Madame Mallory tidak sopan, karena telah melanggar maksim kerendahan hati dengan membanggakan restoran miliknya dan mengatakan, "And that is what he will learn in my kitchen. He will learn how to cook with class. Tuturan diformulasikan dalam bentuk dialog.

\section{c. Penyimpangan}

\section{Kesepakatan}

Prinsip dalam maksim kesepakatan adalah diharapkan peserta tutur mengusahakan agar ketidaksepakatan antara diri sendiri dan pihak lain terjadi sedikit mungkin dan kesepakatan antara diri sendiri dengan pihak lain terjadi sebanyak mungkin. Namun, seringnya peserta tutur menyatakan ketidaksetujuan terhadap suatu masalah atau ide yang diucapkan olaeh lawan tutur sehingga terjadilah penyimpangan pada maksim ini. Pada penelitian ini, penulis memperoleh 16 buah penyimpangan maksim kesepakatan didalam budaya India, dan 11 buah penyimpangan maksim kesepakatan didalam budaya Perancis. Berikut contoh percakapannya:

\section{Budaya India}


Mansur: Oh, really? And where is the family right now, Papa? Huh? Answer me. Where is the family right now? (Oh ya? Dan sekarang dimana keluarga ini, Papa? Huh? Jawab aku. Dimana keluarga saat ini?)

Papa: France. (Perancis)

Mansur: France. France! Exactly. Papa, in case you didn't realize it, the French don't even eat Indian food. They have food of their own. It is famous all over the world. This is the end of the road. Hassan, talk to your father, huh? (Perancis, Perancis! Tepat sekali. Papa, siapa tahu kamu tidak menyadarinya, orang Perancis tidak mengkonsumsi masakan India. Mereka mempunyai makanan khas mereka sendiri. Ini sudah terkenal di seluruh dunia. Inilah akhir dari perjalanan kita. Hassan, bicaralah pada ayahmu, huh?)

Analisa menggunakan teori dari Dell Hymes (2012:58) yang terdiri dari 8 komponen yang biasa disebut SPEAKING:

Dialog didalam film ini berlatar tempat di pinggir jalan, karena mobil yang mereka tumpangi rusak jadi mereka harus berhenti di pinggir jalan. Peserta tutur didalam dialog ini Mansur (anak), dan Papa/ Khadam (ayah). Maksud dari tuturan Mansur adalah dia tidak setuju dengan Khadam tentang pengertian sebuah rumah dan keluarga. Serta Mansur merasa sudah tidak bisa mengajak bicara Khadam lagi karena sudah habis pikirnya, sehingga dia menyuruh adiknya, Hasan untuk berbicara pada Khadam. Dalam dialog ini Mansur terlihat gusar dan berbicara keras pada Khadam karena dia merasa sudah putus asa dengan perbuatan Khadam. Mansur bertutur dengan nada keras dan penuh marah. Tuturan dalam film ini dilakukan dengan lisan tanpa perantara. Tuturan yang diucapkan oleh Mansur tidak sopan dan melanggar maksim kerjasama, dengan tidak menyetujui apa yang dikatakan Khadam, "Oh, really? And where is the family right now, Papa? Huh? Answer me. Where is the family right now?"). Tuturan diformulasikan dalam bentuk dialog.

\section{Budaya Perancis}

Hasan: I'll get it. (Aku akan mengambilnya)

Marguerite: Uh... I don't think that's a good idea. (Uh.... Aku pikir ini bukan ide yang bagus)

Hasan: Why not? (Mengapa tidak?)

Marguerite: Because, um... Because we do the same job, and you know how it is. You know, we get very long days, and we never sleep and we have no time. Chefs shouldn't be together, I think. (Karena, um.. Karena kita melakukan pekerjaan yang sama, dan kamu tahu bagaimana itu. Kamu tahu, hari kerja kita sangat panjang, dan kita tidak pernah tidur dan 
tidak punya waktu. Koki tidak seharusnya bersama, saya pikir.) Analisa menggunakan teori dari Dell Hymes (2012:58) yang terdiri dari 8 komponen yang biasa disebut SPEAKING:

Dialog dalam film ini berlatar tempat di sebuah taman, ada sebuah daun di rambut Marguerite dan Hasan mengambilkannya lalu mereka berciuman. Peserta tutur dalam dialog ini adalah Hasan (koki dari India), dan Marguerite (koki dari Perancis). Maksud dari tuturan Marguerite adalah menolak ajakan Hasan untuk menjalin hubungan cinta dikarenakan kesibukan dari pekerjaan mereka. Dalam dialog ini Margauerite terlihat bingung tetapi dia tidak sepakat dengan ajakan Hasan untuk menjalin hubungan. Margauerite menyampaikan tuturannya denga kebingungan dan sedikit tegas. Tuturan dalam dialog ini dilakukan dengan lisan. Margauerite melakukan pelanggaran terhadap maksim kesepakatan, dikarenaka dia tidak menyetujui ajakan dari Hasan untuk menjalin hubungan cinta dengan mengatakan, "Because we do the same job, and you know how it is. You know, we get very long days, and we never sleep and we have no time. Chefs shouldn't be together, I think." Tuturan diformulasikan dalam bentuk dialog.

\section{SIMPULAN}

Berdasarkan hasil penelitian dari penulis mengenai penyimpangan prinsip kesopanan dalam film The Hundred Foot Journey, penulis menyimpulkan bahwa di dalam film ini ditemukan adanya 3 dari 6 penyimpangan prinsip kesopanan yang dilakukan oleh 2 budaya yang berbeda yaitu India dan Perancis, yang terdiri dari: (1) penyimpangan maksim kebijaksanaan, (2) penyimpangan maksim kerendahan hati, dan (3) penyimpangan maksim kesepakatan. Penyimpangan prinsip kesopanan yang paling sering terjadi di 2 budaya berbeda ini sama-sama maksim kesepakatan, karena dalam percakapan seringkali peserta tutur tidak dapat saling membina kecocokan atau kesepakatan di dalam kegiatan bertutur. Budaya yang sering melakukan pelanggaran maksim kesepakatan adalah budaya India, yang melakukan 16 buah pelanggaran, sedangkan Perancis sebanyak 11 buah pelanggaran.

\section{DAFTAR PUSTAKA}

Chaer, Abdul. (2010). Kesantunan Berbahasa. Jakarta : Rineka Cipta.

Chaer, Abdul dan Leonie Agustina. (2004). Sosiolinguistik Suatu pengantar. Jakarta : Rineka Cipta.

Departemen Pendidikan dan Kebudayaan. (2005). Kamus Besar Bahasa Indonesia. Jakarta : Balai Pustaka.

Leech, Geoffrey. (2013). Principles of Pragmatics. United States of America : Long 
Kunjana, Rahardi. (2015). Kesantunan Imperatif Bahasa Indonesia. Jakarta :Erlangga

Rosada, Amrina. (2016). Analisis Kesantunan Berbahasa Dalam Film Ayat-Ayat Cinta Karya Hanung Bramantyo Sebagai Suatu Kajian Pragmatik. Skripsi S1: Program Studi Pendidikan Bahasa, Sastra Indonesia dan Daerah, Universitas Mataram

Setiyawati, Unun. (2015). Pelanggaran Prinsip Kerjasama dan Prinsip Kesantunan Pada Dialog Ketoprak Asmara Rinaseng Nala. Skripsi S1: Program Studi Pendidikan
Bahasa dan Sastra Jawa, Universitas Negeri Semarang.

Sudaryanto, (2013). Metode dan Aneka Teknik Analisis Bahasa. Yogyakarta : Duta Wacana University Pressman.

Yunitawati, Azizah Malikha. (2013). Penyimpangan Prinsip Kerjasama dan Prinsip Kesopanan Wacana Kartun Pada Buku Politik Santun dalam Kartun Karya Muhammad Mice Misrad. Thesis S2. Surakarta: Program Studi Pengkajian Bahasa, Universitas Muhammadiyah Surakarta. 